\title{
Extraglottic airway devices: technology update [Corrigendum]
}

\author{
Sharma B, Sahai C, Sood J. [Med Devices (Auckl)].
} 2017;10:189-205.

The authors acknowledge that $\mathrm{LMA}^{\circledR}$ is a registered trademark of Teleflex Incorporated or its affiliates and should not have been used as an abbreviation for laryngeal masks generally, or as a suffix, as in "cLMA" and "PLMA". Misrepresentation of the $\mathrm{LMA}^{\circledR}$ trademark and other $\mathrm{LMA}^{\circledR}$ related trademarks was purely unintentional, as is evidenced from the article which places the laryngeal masks of Teleflex Incorporated and those of other companies in different categories.

\section{Publish your work in this journal}

Medical Devices: Evidence and Research is an international, peerreviewed, open access journal that focuses on the evidence, technology, research, and expert opinion supporting the use and application of medical devices in the diagnosis, monitoring, treatment and management of clinical conditions and physiological processes. The identification of novel devices and optimal use of existing devices which will lead to improved clinical outcomes and more effective patient management and safety is a key feature. The manuscript management system is completely online and includes a quick and fair peer-review system. Visit http://www. dovepress.com/testimonials.php to read real quotes from authors. 